\title{
PEMANFAATAN MEDIA SOSIAL SEBAGAI SARANA MEMBUKA PELUANG BISNIS BAGI WARGA DI DESA SINDANGSARI
}

\section{Asye Rachmawaty, Meli Siagawati ${ }^{1}$}

Politeknik LP3I

Email: asyerachmawaty@plb.ac.id,melly.lp3i@gmail.com

\begin{abstract}
Abstrak : Penelitian ini memiliki tujuan menerapkan teknologi internet, khususnya media sosial Facebook dan Instagram untuk membuka peluang bisnis bagi masyarakat Desa Sindangsari Kabupaten garut. Dimana saat ini warga gemar mengakses media sosial hanya untuk meng-update status, dan atau menjaring pertemanan tanpa terpikirkan untuk memulai atau mengembangkan bisnis secara online dengan memanfaatkan kekuatan media sosial tersebut. Pemahaman masyarakat Desa Sindangsari terhadap internet, khususnya media sosial secara umum masih rendah, sehingga pemanfaatan dan fungsi terbesar dari internet (media sosial) itu sendiri terabaikan. Sementara itu tingkat ekonomi masyarakat yang rata-rata berada di level menengah ke bawah, membuat peneliti terpanggil untuk memberikan edukasi kepada masyarakat tentang pemanfaatan internet, khususnya media sosial Facebook dan Instagram serta menjadikannya sarana untuk meningkatkan perekonomian masyarakat Desa. Strategi edukasi yang akan peneliti laksanakan adalah: 1) Membuat pelatihan (Training for Trainer), melalui pelatihan dengan motode ceramah dan praktik menggunakan smartphone milik masing-masing peserta/masyarakat. Pelatihan ini dilaksanakan selama lima kali pertemuan untuk menjadikan peserta sebagai trainer, dimana peserta pelatihan diharapkan mahir dan selanjutnya dapat memberikan edukasi mengenai pemanfaatan media sosial sebagai peluang bisnis kepada masyarakat lainnya. Untuk itu pada pelatihan kali ini, peneliti akan meminta masyarakat mengirimkan 20 peserta pelatihan dari kalangan pelajar, ibu rumah tangga, serta aparat Desa yang dianggap mampu dan memahami cara mengakses internet dengan cukup baik. 2) Membantu masyarakat menemukan atau menciptakan peluang bisnis. Peluang bisnis dapat ditemukan atau diciptakan dengan cara melihat potensi UMKM di Desa tersebut, membuat sesuatu karya baik individu atau berkelompok yang dapat dipasarkan, ataupun dengan menjadi Reseller produk-produk yang sudah terkenal melalui media internet. 3) Membimbing masyarakat dalam memasarkan produk melalui media sosial (Facebook dan Instagram) dan atau Market Place. Adapun target luaran yang peneliti ingin capai berupa jurnal ilmiah yang diterbitkan oleh Politeknik LP3I Bandung.
\end{abstract}

Kata Kunci : Pemanfaatan internet, pemanfaatan media sosial, peluang bisnis.

\section{Pendahuluan}

\subsection{Analisis Situasi}

Indonesia menjadi salah satu negara yang menduduki peringkat teratas pengguna internet di dunia, tepatnya berada di peringkat keenam dan berada di peringkat keempat di Asia 
Tenggara. KOMINFO melalui Siaran Pers No. 53/HM/KOMINFO/02/2018 Tanggal 19 Februari 2018, menyatakan bahwa jumlah pengguna internet tahun 2017 telah mencapai 143,26 juta jiwa atau setara dengan 54,68 persen dari total jumlah penduduk Indonesia. Jumlah tersebut menunjukan kenaikan sebesar 10,56 juta jiwa dari hasil survei pada tahun 2016. Dari 143,26 juta jiwa tersebut terdapat 130 juta orang di Indonesia tercatat aktif sebagai pengguna media sosial. Penelitian yang dilakukan oleh We Are Sosial yang bekerjasama dengan Hootsuite menyatakan bahwa total penduduk Indonesia mencapai 265,4 juta jiwa, dan jika pengguna media sosial adalah 130 juta jiwa, maka sebagian besar pengguna internet adalah pengguna aktif media sosial. Fakta berikutnya disebutkan bahwa penduduk Indonesia menghabiskan waktu rata-rata 8 jam 51 menit menggunakan berbagai fasilitas di internet dan sekitar 3 jam 23 menit menggunakan media sosial setiap harinya. Sementara platform media sosial yang paling banyak diakses oleh netter di Indonesia adalah YouTube 43\%, Facebook 41\%, WhatsApp 40\%, Instagram 38\%, Line $33 \%$, BBM 28\%, Twitter 27\%, Google+ 25\%, Facebook Messenger 24\%, Linkedln 16\%, Skype 15\%, dan WeChat 14\%. (Agus Tri Haryanto, detikinet, 12 Maret 2018).

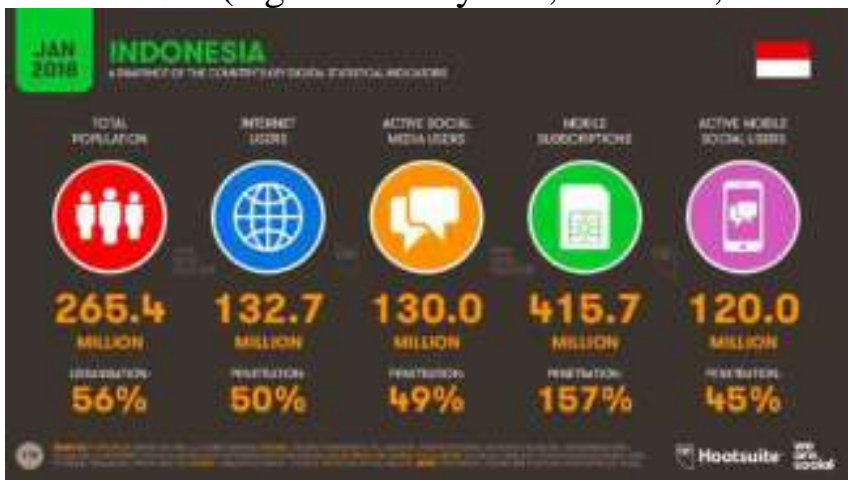

Sumber: Detik.com

Gambar 1. Jumlah Pengguna Internet di Indonesia

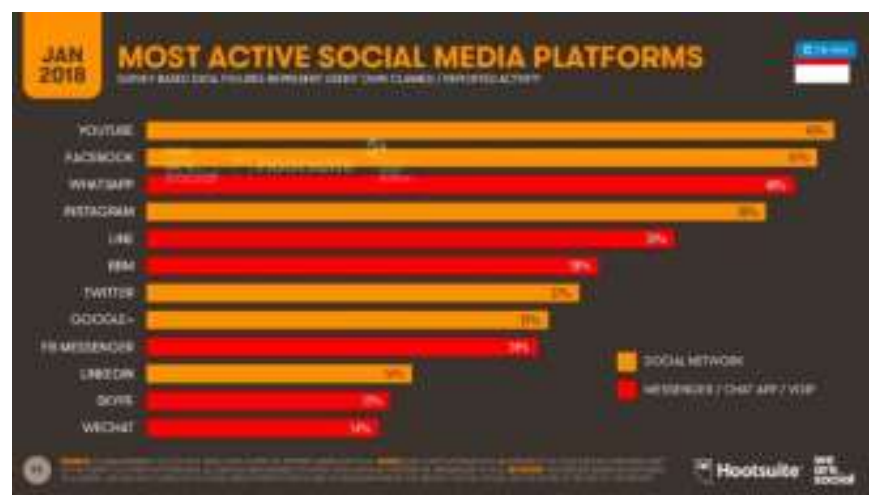

Sumber: Detik.com

Gambar 2. Grafik Keaktifan Pengguna Media Sosial 
Peran internet dalam kehidupan sehari-hari memang tidak dapat dipungkiri lagi. Siapapun hanya dengan berbekal kuota internet dapat mengetahui berbagai informasi yang dibutuhkan dari berbagai platform yang tersedia. Bukan hanya dalam bidang pendidikan dimana berbagai macam e-Book bisa didapatkan melaui internet, bermacam berita di dalam negeri ataupun luar negeri disajikan secara apik, berbagai informasi dunia hiburan yang dapat diakses secara up to date, tetapi juga pemanfaatan internet secara cermat dapat menambah penghasilan yang sangat besar. Hal ini sudah banyak dibuktikan oleh banyak pelaku bisnis online melalui platform YouTube, Instagram, Facebook, Twitter, Market Place, website, dan sebagainya. Saat ini sudah banyak pekerja seni (selebritas) yang juga mencari popularitas melalui channel YouTube dan akun Instagram mereka, bukan hanya menambah popularitas saja tetapi juga menambah penghasilan bagi mereka dengan jumlah followers atau Subscribers yang mencapai angka tertentu. Hal ini tentu saja sangat menggoda bagi mereka yang ingin memiliki popularitas dan juga penghasilan yang tidak sedikit. Sebut saja Atta Halilintar, seorang anak pertama dari 11 bersaudara dari keluarga Halilintar yang memiliki ide kreatif dan keberanian untuk membuat video tentang kehidupan keluarga mereka. Hingga saat ini, channel pribadinya memiliki 17.474.355 subscrubers dari 537 video yang sudah ditayangkan dan dalam satu video mencapai ratarata lima juta viewers. King of YouTube Indonesia ini menjadi YouTuber berpenghasilan tertinggi di Indonesia dengan jumlah penghasilannya mencapai lima miliar rupiah per bulan. Sementara Queen of YouTuber Indonesia diberikan kepada Ria Ricis yang memiliki 15.608.794 subscribers dengan penghasilan mencapai tiga miliar rupiah per bulannya. (Sumber: Fitriana Monica Sari, liputan6.com, 15 Februari 2019)

Contoh lainnya adalah Hendrik Tio seorang Founder Bhineka.com, startup e-commers pertama di Indonesia dan Habibie Afsyah seorang founder Amazon.com yang memiliki keterbatasan fisik namun berpenghasilan miliaran. Mereka berdua sebagian pebisnis yang menggunakan website sebagai sarana mengembangkan bisnisnya. Lalu para pebisnis yang sukses meningkatkan omzet-nya melalui media sosial Instagram, diantaranya Roja Fitridayani dengan akun Instagram @ hijabprincess menawarkan berbagai macam jenis kerudung dan busana muslim kasual yang dipasarkan oleh salah satu selebriti terkenal, sehingga produknya semakin laris di pasaran dan penghasilannya berbisnis online mencapai ratusan juta rupiah per bulan. Banyak contoh para pebisnis yang sukses menggunakan fasilitas internet dalam menjalankan serta mengembangkan bisnisnya.

Dari beberapa contoh di atas, pemanfaatan internet dengan baik menjadi peluang bagi semua netter untuk berkarya dan melakukan berbagai hal positif, seperti: melakukan pembelajaran (tutorial) secara online, membuka dan menjalankan usaha dengan modal terjangkau, meningkatkan popularitas, mendapatkan informasi dengan sangat mudah, menjalin pertemanan dan membuat komunitas, dan sebagainya. Namun sayangnya, sebagian pengguna internet masih belum memahami betul peran internet sebenarnya. Banyak diantaranya yang menggunakan internet untuk hal-hal negatif, seperti: mengakses situs porno, mencari informasi-informasi negatif tentang seseorang atau sesuatu, menyebarkan berita bohong (hoax) karena ketidaktahuan, stalking akun seseorang untuk mencari keburukannya, dan sebagainya. Maka penggunaan internet secara tidak tepat 
akan mengakibatkan munculnya permasalahan-permasalahan dalam kehidupan yang tidak diharapkan, seperti: perceraian, fitnah, perpecahan, pemerkosaan, perjudian, bahkan transaksi haram pun dapat terjadi.

Hal ini tentu saja bisa dicegah jika netter memahami bahwa manfaat-manfaat positifnya jauh lebih banyak dibandingkan manfaat negatif. Pemberian edukasi mengenai penggunaan internet dengan sehat dan bijak menjadi salah satu cara tepat menangani hal ini, tentu saja peran aktif Pemerintah dalam menutup atau membatasi situs-situs negatif pun sangat diperlukan. Meski sebenarnya para pengguna internet pun dapat melakukan pemblokiran terhadap situs atau akun negatif secara pribadi, tetapi jika tidak memahaminya maka hal itu tidak dapat terlaksana juga. Untuk itu peneliti akan mencoba melakukan edukasi pemanfaatan internet, khususnya media sosial kepada masyarakat Desa Sindangsari Kecamatan Leuwigoong Kabupaten Garut.

\subsection{Permasalahan Mitra}

Berdasarkan hasil observasi di lapangan, peneliti menemukan beberapa permasalahan yang terjadi di bidang ekonomi, diantaranya adalah sebagai berikut:

a. Banyaknya para pencari kerja akibat lapangan kerja yang sangat terbatas dan korban pemutusan hubungan kerja (PHK), namun enggan atau bingung untuk memulai berwirausaha;

b. Masyarakat atau para pengusaha kecil/menengah masih menjalankan usahanya secara konvensional tanpa mengetahui teknik pemasaran online dengan target sasaran yang tepat;

c. Keterbatasan ilmu dalam menggunakan smartphone sehingga keberadaannya tidak terlalu menguntungkan bagi masyarakat, khususnya para pelaku usaha;

d. Dalam hal pengetahuan atau ide mengenai teknik pengemasan, pembeian nama usaha, logo, dan tema dari usaha yang dijalani masih sangat rendah;

e. Kurang beraninya mengeluarkan ide, kreatifitas, dan pengembangan diri sehingga perekonomian Desa kurang berkembang.

Melihat kondisi masyarakat Desa yang seperti itu, peneliti tergerak untuk memberikan bantuan berupa edukasi kepada masyarakat mengenai pemanfaatan media sosial sebagai sarana untuk membuka peluang bisnis. Diharapkan dengan pelatihan secara teoritis dan praktik langsung yang kami adakan, masyarakat menjadi terbuka wawasannya mengenai manfaat internet khususnya media sosial untuk meningkatkan kesejahteraan hidup. Kegiatan ini akan dilakukan selama program Pengabdian Kepada Masyarakat berlangsung, yaitu bulan Juli-Agustus 2019 dan jika memungkinkan kegiatan ini akan berlanjut dan dijadikan objek penelitian pada tahun akademik 2019-2020.

\section{Landasan Teori}

Popularitas media sosial telah menciptakan sebuah paradigma baru e-commerce yang disebut social commerce. Social commerce merupakan bagian dari e-commerce dengan memanfaatkan interaksi sosial dan kontribusi pengguna media sosial dalam berbelanja 
online (Kim dan Park, 2013). Dalam social commerce atau media sosial, terdapat interaktivitas antar pengguna. Setiap pengguna dapat melakukan pembaharuan status sementara pengguna lainnya dapat memberikan respon atas status pengguna tersebut, begitu sebaliknya. Replies dan mentions merupakan fitur interaktif pada media sosial yang bergunaa untuk memudahkan pelaku bisnis dalam berkomunikasi dengan konsumen (Lovejoy, Waters, dan Saxton, 2012). Pertimbangan penting dalam mengadopsi media sosial adalah interaktivitas, karena fitur interaktivitas dapat menjembatani adanya gap yang disebabkan oleh perbedaan waktu dan lokasi geografis antara penjual dan konsumen (Michaelidou dkk, 2011). Pada penelitian sebelumnya, Anissa Hakim Purwantini dan Friztina Anisa (2018) mengemukakan bahwa interaktivitas berpengaruh terhadap penggunaan media sosial bagi UMKM. Ketersediaan komunikasi dua arah secara interaktif antara penjual dan konsumen menjadi faktor penting dalam penggunaan media sosial. Media sosial seperti facebook dan instagram menyediakan fitur interaktif seperti menu obrolan pribadi,replies dan mentions/tag yang memudahkan pelaku bisnis untuk menjalin komunikasi dengan konsumen. Adanya fitur interaktivitas tersebut dapat mempercepat respon penjual terhadap kebutuhan konsumen karena menjembatani perbedaan waktu dan lokasi antara penjual dan konsumen. Fitur interaktif yang ditawarkan media sosial dapat menjadi wadah bagi penjual dan pelanggan untuk melakukan co-creation terhadap produk. Sehingga keinginan konsumen seperti kustomisasi produk dapat terfasilitasi melalui fitur yang ada pada media sosial. Peran media sosial pun berpengaruh pada kinerja pebisnis baik secara keuangan ataupun non keuangan.

Terdapat lima poin peran media sosial dalam dunia pemasaran telah dikemukakan oleh Neti (2011) dalam penelitiannya yaitu:

a. Media sosial dapat memberikan identitas mengenai produk yang ditawarkan.

b. Berperan sebagai penelitian pemasaran dalam usaha mencari informasi mengenai kebutuhan konsumen.

c. Media sosial dapat dijadikan sebagai penghubung komunikasi antara pemasaran dengan konsumen, hal ini bertujuan untuk mempertahankan hubungan dengan konsumen.

d. Media sosial mendekatkan perusahaan dengan konsumen. Konsumen dapat mereduksi waktu yang mungkin digunakan hanya untuk melihat produk secara langsung, media sosial berfungsi untuk menampilkan produk setiap waktu.

e. Media sosial ditujukan untuk membangun customer engagement.

Hal ini telah diuji coba juga oleh Made Resta Handika, Agus Fredy Maradona, dan Gede Sri Darma (2018) dalam penelitiannya yang mengemukakan bahwa lima poin peran media sosial dalam pemasaran itu sejalan dengan hasil wawancara yang mereka lakukan dalam penelitian.

\section{Metodologi dan Tahapan Penelitian}

\subsection{Metodologi Penelitian}

Terdapat beberapa motede dalam melaksanakan program penelitian untuk memberikan solusi bagi mitra, diantaranya adalah sebagai berikut: 
a. Melakukan observasi lapangan dan wawancara kepada pihak-pihak terkait, dalam hal ini masyarakat; para pelaku usaha; para pencari kerja, dan aparatur Desa untuk mengetahui keadaan dan permasalahan yang dihadapi mitra.

b. Mendapatkan data-data terkait yang diperlukan selama kegiatan berlangsung, dalam hal ini jenis-jenis usaha, sistem pengelolaannya, pemasarannya, dan pemahaman tentang optimalisasi internet.

c. Memberikan sosialisasi kepada mitra sebelum pelatihan dimulai, bahwa pelatihan akan dilaksanakan secara intensif dan berkelanjutan.

d. Memberikan pelatihan kepada mitra, baik secara teori maupun praktik dalam upaya meningkatkan sumber daya manusia, terutama di bidang usaha. Tahapan ini adalah tahapan yang paling utama dari semua tahap. Karena salah satu solusi permasalahan mitra adalah dengan pemanfaatan dan optimalisasi pengelolaan media sosial guna meningkatkan penjualan.

Menurut Dewa Eka Prayoga dalam bukunya yang berjudul Main Facebook (2018), terdapat tiga poin dalam melakukan bisnis online melalui akun Facebook, yaitu:

1) Scrolling, terbagi menjadi tiga tahapan yaitu: searching, screening, dan spying. Searching meliputi kegiatan mencari ide konten, ide copywriting, ide angle, ide gambar, dan ide produk. Screening meliputi kegiatan menyaring pertemanan, memilih/mencari influencer, dan mencari prospek atau calon buyer. Spying, hal ini dilakukan kepada para pesaing, meliputi kegiatan mengintip produk yang dijual, penawaran yang ditawarkan, harga yang ditetapkan, gambar yang digunakan, dan copywriting yang dipakai.

2) Posting, terbagi menjadi tiga tahapan yaitu: planning, creating, dan sharing. Planning meliputi kegiatan merencanakan publish date, post type, angle, offer, image, headline, CTA, tagging, album, dan keyword. Creating adalah usaha membuat status menjadi viral dan diperhaikan banyak orang. Sharing adalah membuat status yang memotivasi, menginspirasi, mengedukasi, memprovokasi, mengompori, dan atau menghibur.

3) Closing, terbagi atas tiga tahapan yaitu: giring, pancing, dan cring-cring. Mengiring calon buyer dari tidak tahu menjadi tahu, dari tahu menjadi suka, dari suka menjadi tertarik, dari tertarik menjadi yakin, dan dari yakin menjadi beli. Memancing calon buyer dengan empat fitur bawaan Facebook seperti profile cover, album photo. Post filters, dan search. Terdapat dua cara yang dapat dilakukan untuk tahapan cring-cring, yaitu mengarahkan ke WhatsApp dan atau mengarahkan ke Website.

\section{2 Tahapan Penelitian}

Adapun tahapan untuk menyelesaikan permasalahan mitra, setidaknya mengurangi masalah-masalah tersebut, peneliti mencoba melakukan beberapa hal, yaitu:

a. Menemukan dan Menciptakan Peluang Bisnis

Membantu masyarakat menemukan atau menciptakan peluang bisnis. Peluang bisnis dapat ditemukan atau diciptakan dengan cara melihat potensi UKM di Desa tersebut. 
UKM yang memproduksi es krim, telur asin, dan keripik singkong adalah tiga jenis usaha melalui UKM, baik secara perorangan atau kelompok kecil, yang dapat dijadikan contoh sumber peluang bisnis. Dari ketiga UKM tersebut, jika masyarakat menggali lebih lanjut maka diharapkan masyarakat mendapatkan ide untuk menciptakan pengembangan usaha yang berdasar pada ketiga UKM. Seperti membuat beberapa varian rasa untuk keripik singkong yang dapat memuaskan konsumen pecinta keripik. Dengan ini diharapkan masyarakat mampu membuat suatu karya baik individu atau berkelompok yang dapat dipasarkan secara online dan offline.

b. Membuat pelatihan (Training for Trainer)

Melalui pelatihan dengan motode ceramah dan praktik menggunakan smartphone milik masing-masing peserta/masyarakat. Pelatihan ini dilaksanakan selama lima kali pertemuan untuk menjadikan peserta sebagai trainer, dimana peserta pelatihan diharapkan mahir dan selanjutnya dapat memberikan edukasi mengenai pemanfaatan media sosial sebagai peluang bisnis kepada masyarakat lainnya. Untuk itu pada pelatihan kali ini, peneliti akan meminta masyarakat mengirimkan 20 peserta pelatihan dari kalangan pelajar, bapak/ibu rumah tangga, serta aparat Desa yang dianggap mampu dan memahami cara mengakses internet dengan cukup baik. Diharapkan melalui pelatihan ini, lahirlah para trainer yang mahir dalam penggunaan media sosial secara optimal sebagai salah satu teknik pemasaran.

c. Memperkenalkan sistem reseller dan dropshiper

Dalam memulai atau menjalankan bisnisnya, masyarakat yang diharapkan dapat melakukan pemasarkannya melalui akun media sosial mereka, juga mengetahui sistem reseller dan dropshiper sebagai salah satu peluang memulai bisnis. Untuk saat ini terutama bagi pemula yang belum memiliki ide kreatif untuk membuat suatu produk sendiri, sistem ini dapat dijadikan target utama, karena dengan sistem ini masyarakat tidak perlu memiliki modal besar untuk menjadi seorang pebisnis, target pasar pun tidak hanya mereka yang berada di kawasan Kabupaten Garut saja tetapi seluruh Indonesia.

d. Memperkenalkan Pemasaran Melalui Market Place

Memperkenalkan dan membimbing para pelaku usaha untuk memasarkan produknya melalui Market Place untuk meningkatkan penjualan dan memperluas jaringan konsumen.

e. Mengelola Akun Media Sosial

Memberikan edukasi mengenai pentingnya pemberian nama sebagai merek dagang, logo, tema, dan konten pada akun media sosial dan pada setiap iklan yang duunggah melalui akun bisnis. Pada teknik pemasaran secara online, perlakuan seperti ini adalah hal utama yang sangat penting agar calon konsumen tertarik melihat akun media sosial yang dibuat. Termasuk pengelolaan akun bisnis dalam media sosial dan optimalisasinya baik secara gratis atau berbayar.

f. Mengemas dan Mengirim dengan Benar 
Memberikan edukasi dan wawasan mengenai teknik pengemasan dan pengiriman melalui jasa ekspedisi, kurir, ataupun COD.

Untuk melaksanakan kegiatan edukasi tersebut, peneliti akan bekerja dengan aparat Desa sebagai pemilik kewenangan atas wilayah dan masyarakat; UMKM/BUMDes sebagai wadah pengelolaan usaha di Desa yang menaungi kelompok-kelompok usaha; pelajar SMA/SMK sebagai generasi muda milenial yang dianggap mahir dalam menggunakan internet, lebih mudah menyerap ilmu, dan diharapkan lebih kreatif; serta ibu-ibu PKK sebagai penggerak masyarakat Desa, diharapkan dapat menyebarkan isu-isu positif tentang kegiatan ini sehingga masyarakat tertarik untuk bergabung dalam kegiatan pelatihan ini.

Target capaian dari kegiatan pelatihan pemanfaatan media sosial untuk membuka peluang bisnis ini adalah masyarakat mulai terbuka dan berani memulai bisnis hasil produksi ataupun reseller dengan menjadikan media sosial sebagai sarana pemasaran dan transaksinya hingga dapat mengemas produk yang akan dikirimkan dengan kemasan menarik serta aman ketika dikirimkan melalui jasa ekspedisi. Dengan berjalannya bisnis online ini diharapkan dapat meningkatkan keadaan ekonomi masyarakat, mengurangi tingkat pencari kerja, menekan angka kemiskinan, membuka peluang bisnis yang lebih besar lagi, dan meningkatkan kesejahteraan sosial masyarakat Desa Sindangsari secara umum.

\section{Pembahasan}

4. 1 Gambaran Umum

\begin{tabular}{|lll|}
\hline Nama Lokasi & $: \begin{array}{l}\text { Desa Sindangsari, Kecamatan } \\
\text { Leuwigoong, Kabupaten Garut }\end{array}$ \\
\hline Nama Kepala Desa & $:$ & Drs. Kusnadi Hermawan Sukinda \\
\hline $\begin{array}{l}\text { Sumber Mata Pencaharian } \\
\text { Warga Rata-rata }\end{array}$ & $: \begin{array}{l}\text { Petani padi/jagung, pedagang/pengusaha } \\
\text { kecil }\end{array}$ \\
\hline UKM & $:$ Es Krim, Telur Asin, Keripik \\
\hline Metode Pemasaran & $: \begin{array}{l}\text { Konvensional dengan berjualan keliling } \\
\text { atau dijual titip di warung-warung }\end{array}$ \\
\hline Pengguna produk & $:$ Masyarakat Sekitar dan Umum \\
\hline Warga Pengguna Internet & $:$ & Ya \\
\hline Warga Pengguna Media Sosial & $:$ & Ya \\
\hline
\end{tabular}




\begin{tabular}{|ll|}
\hline Fasilitas Desa & $: \begin{array}{l}\text { Terdapat jaringan Hot Spot di Kantor } \\
\text { Desa dan sekitarnya }\end{array}$ \\
\hline
\end{tabular}

Sumber: Profil Desa Sindangsari

Desa Sindangsari, secara geografis terletak di Kecamatan Leuwigoong, Kabupaten Garut dan memiliki luas wilayah 315,696 Ha yang terdiri dari dua Dusun dengan 16 Rukun Warga dan 42 Rukun Tetangga. Desa ini memiliki batas wilayah administratif dengan Desa Leuwigoong Kecamatan Leuwigoong di sebelah Utara, Desa Cimareme Kecamatan Banyuresmi di sebelah Selatan, Desa Dungusiku Kecamatan Leuwigoong di sebelah Barat, dan Desa Kertajaya Kecamatan Cibatu di sebelah Timur. Kepala Desa Sindangsari untuk periode 2015 s.d. 2021 adalah Kusnadi Hermawan.

Berdasarkan Profil Desa Sindangsari tahun 2018, Desa Sindangsari memiliki potensi sumber daya manusia di tahun 2018 sebanyak 8259 jiwa terdiri dari 4238 laki-laki dan 4021 perempuan. Jumlah guru dan murid tiap tahunnya mengalami peningkatan dimana jumlah guru sebanyak 74 orang dengan jumlah murid PAUD sebanyak 65 orang, TKA sebanyak 20 orang, SD sebanyak 848 orang, SLTP sebanyak 350 orang, dan SLTA sebanyak 873 orang. berdasarkan data 2018, terdapat 488 KK masyarakat miskin dan 122 rumah tidak layak huni, hal ini disebabkan keterbatasannya lapangan pekerjaan sementara jumlah pencari kerja yang cukup banyak. Kenaikan BBM dan krisis moneter pun menambah keadaan semakin buruk, akibatnya banyak para pekerja di-PHK. Hal ini memberikan kontribusi sangat besar terhadap jumlah pencari kerja yang tidak terproyeksikan sebelumnya. Jumlah pencari kerja pada tahun 2017 sebanyak 725 orang yang terdiri dari 322 orang laki-laki dan 403 orang perempuan.

Namun demikian, rata-rata masyarakat Desa Sindangsari saat ini memiliki smartphone, baik di kalangan remaja ataupun dewasa. Bahkan tidak sedikit anak-anak di bawah umur pun meminjam smartphone orang tuanya untuk mengakses YouTube atau sekedar bermain games. Ibu-ibu, bapak-bapak, remaja dan anak-anak memiliki akun media sosial meski sebagain besar para orang tua dan anak kecil memilikinya dengan cara dibuatkan oleh orang lain, entah itu anak remajanya atau penjual smartphone-nya yang memberikan fasiltas gratis/berbayar pemasangan beberapa aplikasi dan pembuatan akun media sosial saat membeli smartphone tersebut. Bahkan mereka banyak yang tidak mengetahui bagaimana cara membuat email, sebagai salah satu syarat utama membuat akun media sosial. Sementara berdasarkan Profil Desa Sindangsari tahun 2018, sumber mata pencaharian bagi sebagian masyarakat adalah sebagai petani padi atau jagung, dan sebagian lagi pedagang kecil, warung, dan ojeg yang serba konvensional.

4. 2 Karakteristik Responden

Distribusi Responden berdasarkan jenis kelamin, umur, pekerjaan, dan pendidikan terakhir dapat dilhat pada tabel berikut:

Tabel 1. Distribusi Responden 


\begin{tabular}{|c|l|r|r|}
\hline No. & \multicolumn{1}{|c|}{ Variabel } & Frekuensi & Persentase (\%) \\
\hline 1 & Jenis Kelamin & & \\
& a. Laki-laki & 8 & 40 \\
& b. Perempuan & 12 & 60 \\
\hline 2 & Umur & 4 & 20 \\
& a. $15-24$ & 10 & 50 \\
& b. $25-34$ & 6 & 30 \\
\hline 3 & c. $35-44$ & & \\
& Pekerjaan & 4 & 20 \\
& a. Pelajar & 12 & 60 \\
& b. Wirasawasta/Ibu Rumah Tangga & 4 & 20 \\
\hline 4 & c. Aparat Desa & 2 & 10 \\
& Pendidikan Terakhir & 8 & 40 \\
& a. SD/Sederajat & 10 & 50 \\
\hline & b. SMP/Sederajat & & \\
& c. SMA/Sederajat & & \\
\hline
\end{tabular}

Berdasarkan tabel berikut di atas, dapat disimpulkan bahwa penelitian ini melibatkan responden (peserta pelatihan) yang rata-rata pada masa produktif dan memiliki pendidikan menengah, sehingga daiharapkan peran aktif masyarakat dalam penelitian ini lebih tinggi.

\section{3 Hasil Penelitian}

Penelitian dilakukan dengan metode pemberian pelatihan dan praktik yang terdiri dari enam tahap, yaitu: a) menemukan dan menciptakan peluang bisnis; b) membuat pelatihan internet; c) memperkenalkan sistem reseller dan dropshiper; d) memperkenalkan pemasaran melalui market place; e) mengelola akun media sosial; serta f) mengemas dan mengirim dengan benar.

Tahap Satu yaitu menemukan dan menciptakan peluang bisnis bagi masyarakat setempat. Pada tahapan ini, peserta pelatihan diajak untuk membuka wawasan bagaimana melihat peluang bisnis dengan cara sebagai berikut:

a. Melihat potensi daerah sekitar Desa Sindangsari, Kota Garut, Jawa Barat, dan Indonesia. Hal ini tergantung pada kemampuan suber daya manusia, jenis produk yang akan dihasilkan, juga seperti apa pemasaran produk nantinya.

b. Mencari tahu kebutuhan masyarakat sekitar. Hal ini berkaitan dengan pangsa pasar yang menjadi target penjualan.

c. Bekerjasama dengan usaha lainnya. Peserta juga diajarkan untuk mencari mitra dalam melakukan bisnis, jika kurang memungkinkan karena keterbatasan modal, peserta diarahkan menjadi reseller dan dropshiper sebagai langkah awal.

d. Memulai dari hobi. Peluang bisnis sangat memungkinkan berasal dari hobi, seperti: hobi memasak menjadi sebuah peluang untuk memulai bisnis catering. 
e. Mencari peluang usaha melalui internet. Terdapat banyak peluang usaha yang dapat dicari melalui berbagai situs di internet.

f. Memulai dengan menciptakan hal baru yang belum pernah ada sebelumnya, memodifikasi produk yang sudah ada menjadi berbeda, atau hanya sekedar menambahkan varian rasa tertentu dalam makanan.

g. Melihat peluang usaha dari bakat diri sendiri. Tidak jauh berbeda dengan hobi, dengan mengetahui bakat diri sendiri dan mengembangkannya maka dapat menjadi peluang bisnis.

Pada tahapan ini, peserta pelatihan secara perlahan mulai terbuka wawasan mengenai peluang bisnis melalui tujuh cara di atas.

Tahap Dua yaitu membuat pelatihan mengenai penggunaan internet dalam kehidupan pribadi, sosial, bisnis, yang termasuk dalam etika berinternet. Peserta diajak untuk menggunakan internet dengan aman dan beretika dengan cara:

a. Menggunakan internet untuk hal positif dan tidak merugikan orang lain

b. Mematuhi dan tidak mengganggu hak orang lain dalam berkarya

c. Bersikap baik dan tidak memata-matai pengguna lain

d. Tidak menggunakan internet untuk menyebarkan berita HOAX atau kesaksian palsu

e. Hati-hati ketika menduplikasi atau menyebarkan informasi

f. Tidak mencuri dan melakukan penipuan terhadap pengguna lain

g. Mempertimbangkan konsekuensi dari program yang dibuat atau sistem yang dirancang

h. Saling menghormati sesama pengguna internet.

Pada tahap ini, peserta mulai mengetahui bagaimana menggunakan internet dengan baik, aman, dan beretika sehingga diharapkan bertambahnya para pengguna internet secara positif dan bermanfaat dalam berbisnis.

Tahap Tiga yaitu memperkenalkan sistem reseller dan dropshiper sebagai alternatif bisnis bagi pemula dengan modal terbatas. Peserta diberikan pemahaman mengenai reseller dan dropshiper, cara kerja kedua sistem tersebut, keuntungan serta kerugiannya, serta tips dan trik menjadi reseller dan dropshiper sukses untuk pemula. Peserta dengan keterbatasan kemampuan dalam produksi dan juga peserta yang masih berstatus pelajar lebih tertarik dengan kedua sistem ini dan mulai mencari supplier-supplier yang memproduksi atau menyediakan produk-produk yang ingin mereka pasarkan. Sementara para mengrajin atau peserta yang memang sudah memiliki bisnis lebih tertarik mencari mitra sebagai reseller dan dropshiper produk-produk mereka.

Tahap Empat yaitu memperkenalkan pemasaran melalui Market Place. Peserta diperkenalkan dengan 10 Market Place terbaik di Indonesia pada tahun 2019, seperti: 1) Blanja.com; 2) Bukalapak.com; 3) Lazada Indonesia; 4) FJB Kaskus; 5) Tokopedia; 6) OLX Indonesia; 7) Bhineka.com; 8) Blibli.com; 9) Elevenia; dan 10) Zalora Indonesia. Beberapa peserta, terutama pelajar tampak sudah pernah melakukan transaksi (belanja online) melalui salah satu situs Market Place di atas. namun sebagian besar hanya sering mendengar saja tanpa tahu manfaatnya. Setelah diberikan penjelasan serta bagaimana 
cara menjadi member beberapa Market Place tersebut, peserta diharapkan menjadi lebih semangat dalam melakukan bisnis.

Tahap Lima yaitu mengelola akun media sosial baik penggunaannya sebagai akun pribadi atau bisnis. Peserta diberikan pemahaman dan praktik bagaimana membuat akun media sosial pribadi dan bisnis dalam Facebook dan Instagram. Peserta juga diajarkan mengenai tiga poin (scrolling, posting, closing) dalam melakukan bisnis online menurut Dewa Eka Prayoga dan bagaimana melakukannya secara konsisten dan berkelanjutan. Hingga tahapan ini, peserta mulai terbiasa dengan rajin melakukan interaksi dengan akunakun target pemasarannya. Peserta juga mulai belajar membuat caption baik itu berupa informasi bermanfaat, motivasi ringan mengenai kehidupan, bahkan sekedar humor sederhana dengan harapan dilirik akun-akun target. Memang hingga tahapan ini, belum ada closing melalui media sosial ataupun market place, namun peserta merasakan perubahan dalam pertemanannya melalui akun media sosial.

Tahap Enam yaitu mengemas dan mengirim dengan benar. Meski belum mendapatkan pesanan yang harus dikemas dan dikirimkan melalui jasa pengiriman barang, namun peserta pelatihan tetap melakukan praktik bagaimana cara mengemas paket dengan benar, aman, dan rapih sehingga diharapkan sampai dalam keadaan baik dan produk tidak cacat. Pemilihan ekspedisi pengiriman barang yang terpercaya dan amanah serta cara melacak keberadaan paket pun menjadi bagian dari pelatihan.

\section{Kesimpulan}

Berdasarkan hasil penelitian yang sudah dilakukan, dapat ditarik kesimpulan untuk menjawab permasalahan mitra sebagai berikut:

a. Para pencari kerja dan korban PHK diharapkan mulai terbuka wawasannya untuk mencari peluang bisnis sebagai sumber pendapatan

b. Pengusaha kecil/menengah yang masih menjalankan bisnisnya secara konvensional, melalui pelatihan ini diharapkan mau mengembangkan usahanya secara online sehingga tercipta peningkatan pendapatan

c. Penggunaan smartphone lebih pesitif dan tepat guna sehingga lebih bermanfaat bagi masyarakat, terutama pelaku bisnis

d. Pengetahuan atau ide mengenai teknik pengemasan, pembeian nama usaha, logo, dan tema dari usaha yang dijalani lebih dipahami sehingga calon pembeli semakin tertarik

e. Masyarakat lebih berani mengeluarkan ide, kreatifitas, dan pengembangan diri sehingga diharapkan perekonomian Desa meningkat.

\section{Daftar Pustaka}

[1] Anissa Hakim Purwantini, Friztina Anisa. (2018). Analisis Pemanfaatan Social Commerce bagi UMKM: Anteseden dan Konsekuen. Kompartemen: Jurnal Ilmiah Akuntansi. XVI(1), 47-63.

[2] Dewa Eka Prayoga. (2018). Main Facebook. PT Kiblat Pengusaha Indonesia. ISBN 9786025205576, Cetakan Pertama. 
[3] Kim, S., \& Park, H. 2013. Effects of Various Characteristics of Social Commerce (S-Commerce) on Consumers' Trust and Trust Performance. International Journal Of Information Management, 33(2): 318-332. https://doi.org/10.1016/j.ijinfomgt.2012.11.006.

[4] Lovejoy, K., Waters, R. D., \& Saxton, G. D. 2012. Engaging Stakeholders

Through Twitter: How Nonprofit Organizations ArelNgetting More Out of 140

Characters or Less. Public Relations Review, 38(2): 313-318.

https://doi.org/10.1016/j.pubrev.2012.01.005.

[5] Made Resta Handika, Agus Fredy Maradona, Gede Sri Darma. (2018). Strategi Pemasaran Bisnis Kuliner Menggunakan Influencer Melalui Media Sosial Instagram. Jurnal Manajemen dan Bisnis. Volume 15,No. 2, http://journal.undiknas.ac.id/index.php/magister-manajemen/

[6] Michaelidou, N., Siamagka, N. T., \& Christodoulides, G. 2011. Usage, Barriers and Measurement of Social Media Marketing: An Exploratory Investigation of Small And Medium B2B Brands. Industrial Marketing Management, 40(7), 1153-1159. https://doi.org/10.1016/j.indmarman.2011.09.009.

[7] Neti, S. (2011). Social media and its role in marketing, International Journal of Enterprise Computing and Business Sistems, 1 (2): 1-16.

[8] Profil Desa Sindangsari Kecamatan Leuwigoong Kabupaten Garut Tahun 2018. (2018). Garut, Indonesia.

[9] https://m.detik.com/inet.cyberlife/d-39129/130-juta-orangindonesia-tercatat-aktifdi-medsos

[10] https://kominfo.go.id/index.php/content/detail/12640/siaran-pers-no53hmkominfo022018-tentang-jumlah-pengguna-internet-2017-meningkatkominfo-terus-lakukan-percepatan-pembangunan-broadband/0/siaran_pers

[11] https://www.liputan6.com/bisnis/read/389418/10-youtuber-indonesiaberpenghasilan-fantastis-siapa-saja 